\title{
Petrology of the Mavillette Intrusion Digby County, Nova Scotia
}

\author{
Lynn $M$. Calder and Sandra $M$. Barr \\ Department of Geology, Acadia University, Wolfville, N.S. BOP IXO
}

\begin{abstract}
The Mavillette Intrusion is a small gabbroic body located in Digby County, southwestern Nova Scotia. It is dyke-like in form, trending about $150^{\circ}$, with a strike length of at least $1250 \mathrm{~m}$ and $a$ width of about $100 \mathrm{~m}$. The igneous mineralogy includes oligoclase-andesine and augite, with accessory magnetite, ilmenite, and apatite, but the intrusion has undergone variably intense alteration/low-grade metamorphism and shearing, and secondary minerals are abundant. In chemical composition the intrusion is highly evolved but probably of continental tholeitic affinity. It differs from other mafic igneous rocks of southern Nova Scotia, but on the basis of geographic location, mineralogy, and chemistry is considered to be related to the volcanic rocks of the White Rock Formation in the Cape St. Mary's - Yarmouth area. This correlation implies a late ordovician-early Silurian age for the intrusion.
\end{abstract}

L'intrusion Mavillette est une petite masse gabbrơqque située dans le comté de Digby au sud-ouest de la Nouvelle-Ecosse. Elle adopte la forme d'un dyke d'une largeur d'environ $100 \mathrm{~m}$ et suit une direction d'azimut 150 sur. une longueur d'au molns $1250 \mathrm{~m}$. La minéralogie ignée comprend des plagioclases (oligoclase-andésine) et de l'augite, avec comme minéraux accessoires de la magnétite, de I'ilménite et de 1'apatite. Les minéraux secondaires sont très abondants car l'intrusion a subi les effets variés d'une altération intense et d'un métamorph1sme lëger, accompagnés d'un cisaillement. La composition chimlque de l'intrusion est très développée mals reflète probablement une affinité tholéiltique continentale. L'intrusion diffère des autres roches ignées mafiques du sud de la Nouvelle-Ecosse, mais de par sa situation géographique, sa minéralogie et sa chimle, on la considère relièe aux roches volcaniques de la formation White Rock qu'on retrouve dans la région de Cape St. Mary's - Yarmouth. Cette corrélation donne à i'Intrusion un âge allant de l'Ordovicien tardif au début du Silurien.

[Traduit par le journa1]

\section{INTRODUCTION}

The Mavillette Intrusion is a small gabbroic body located $2.5 \mathrm{~km}$ north of Mavillette in Digby County, Nova Scotia (Fig. 1). The known outcrop of the intrusion covers an area of approximately $0.03 \mathrm{~km}^{2}$ within slates of the CambroOrdovician Halifax Formation (Taylor 1969). No detailed investigation of the Mavillette Intrusion had previously been undertaken, and its age, form, areal extent, and general petrology were poor$1 y$ documented. The purpose of this study is to describe these aspects of the intrusion, and to determine its magmatic affinity, the tectonic setting in which it was emplaced, and its possible relation to other mafic igneous occurrences in southern Nova Scotia.

\section{METHODS}

Field studies included a magnetic survey in the vicinity of known outcrops

MARITIME SEDIMENTS AND ATLANTIC GEOLOGY $18,29-40(1982)$ of the intrusion using a Barringer Proton Precession Magnetometer. Lines were oriented approximately north - south, with a spacing of about $20 \mathrm{~m}$. An enlargement (approximate scale 1:2100) of the colour aerial photograph (Maritime Resource Management Service Photo 783059) covering the area was used as a base map. Outcrops in the survey area (Fig. 2) were examined, and representative samples collected for petrographic studies and chemical analyses.

Major element analyses were done by atomic absorption spectrometry except $\mathrm{Na}$ and $\mathrm{K}$ which were determined by flame photometry. The method is modified from Buckley and Cranston (1971) and is described by Calder (1981). Loss on ignition was determined as percentage weight lost during heating for one hour at $1000^{\circ} \mathrm{C} . \mathrm{P}, \mathrm{Ni}, \mathrm{Cr}, \mathrm{Zr}$, and $\mathrm{Y}$ were done commercially at CLIM Laboratories, Technical University of Nova Scotia, by colorimetry (P) and quantitative emission spectrography $(\mathrm{Ni}, \mathrm{Cr}, \mathrm{Zr}, \mathrm{Y})$. 


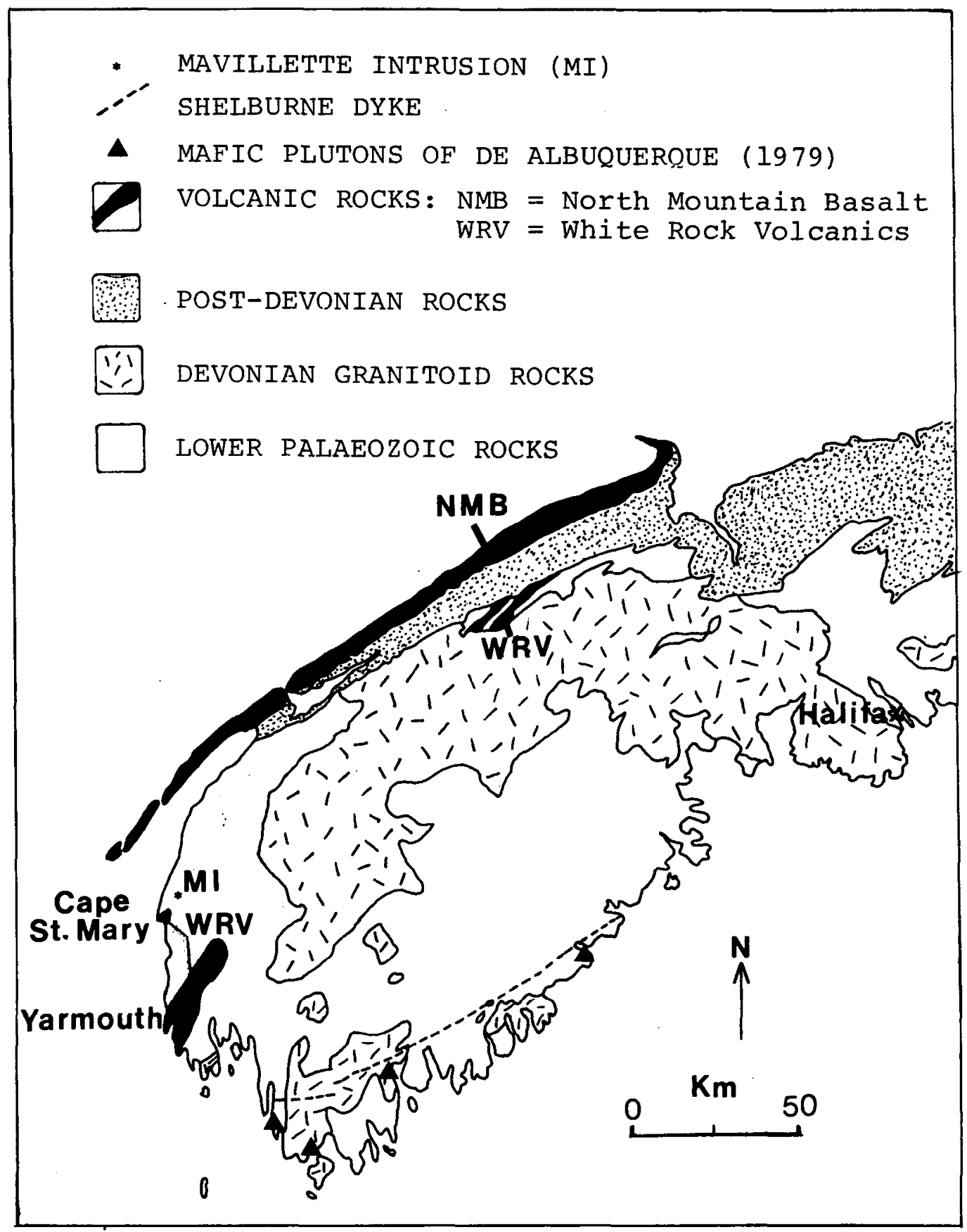

Fig. 1 - Geological sketch map of southern Nova Scotia showing the location of the Mavillette Intrusion and other mafic igneous rocks. Modified from Keppie (1979).

$\mathrm{Ba}$ was determined by $\mathrm{X}$-ray fluroescence at Acadia University, and $\mathrm{Nb}$ and $\mathrm{Rb}$ by $\mathrm{X}$-ray fluorescence at St. Mary's University.

\section{FIELD RELATIONS}

Outcrop in the area is generally poor. However, the gabbro has been well ex- posed by quarrying in the central part of the study area (Fig. 2). The rocks are used primarily for construction of breakwaters. Contacts of the intrusion with its country rocks are not exposed, but the finer grained outcrop at locality 18 (Fig. 2) is probably a chilled margin. A nearby small outcrop of slate 


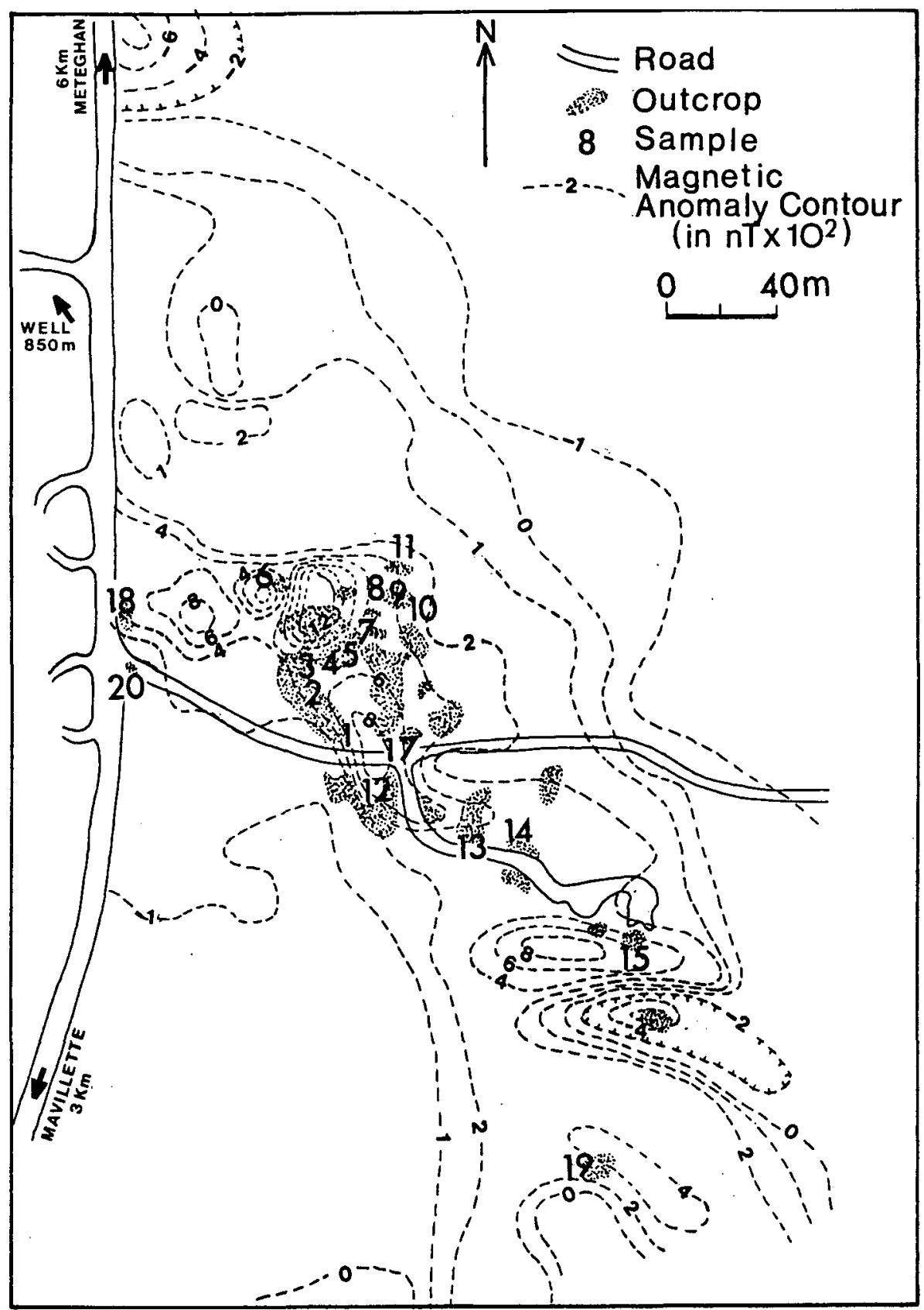

Fig. 2 - Magnetic contours over the Mavillette Intrusion. Survey lines are oriented north-south, spacing approximately $20 \mathrm{~m}$. Base map and outcrops are taken from enlargement of aerial photograph 78305-9 (Maritime Resource Management Service).

at locality 20 does not display evidence of contact metamorphism.

The ground magnetic survey over the intrusion revealed a strong magnetic anomaly pattern about $100 \mathrm{~m}$ in width trending approximately $150^{\circ}$ (Fig. 2). The intrusion is characterized by ir- regular anomalies and closed contours typical of mafic igneous rocks. As the regional trend within the Halifax Formation in the area is north-northeast (Taylor 1969), the intrusion is strongly discordant and hence dyke-like in form. It apparent1y continues farther north- 
west and southeast outside the survey area. In fact, similar gabbro was encountered during drilling of a water we11 $850 \mathrm{~m}$ northwest of the area (R.H. MacNeill, pers. comm. 1981), giving a minimum strike length of $1250 \mathrm{~m}$. However, the intrusion is not apparent on the aeromagnetic map of the area (Department of Mines and Technical Surveys, 1956) with an east-west flight line spacing less than $1 \mathrm{~km}$, so it is unlikely that the dyke extends more than a few kilometres along strike, unless its magnetic signature is too weak to be detected by an aeromagnetic survey. The latter is probably not the case, as the Shelburne dyke gave a ground magnetic response only approximately twice that of the Mavillette Intrusion (Lawrence 1966) and yet shows a very prominent linear anomaly on aeromagnetic maps of the same series referred to above.

The cause of the large anomalies cutting across the dyke in the southeastern part of the survey area is not clear (Fig. 2). However, minor shear zones typically trending northeast-southwest to east-west are common. within the exposed part of the intrusion, and hence one or more major offsets may be the cause of these anomalies.

\section{PETROGRAPHY}

Most of the intrusion is composed of medium-grained gabbro, buff to brown on weathered surfaces and dark green or grey on fresh surfaces. It consists predominantly of plagioclase (oligoclaseandesine), augite, and their alteration products (albite, sericite, chlorite, actinolite, and minor carbonate, epidote, and hematite). Opaque minerals (predominantly ilmenite altered to leucoxene, and magnetite, with minor pyrite and pyrrhotite) comprise $2-5 \%$ of the rock and apatite $2-6 \%$. Interstitial quartz and albite, probably secondary, are recognizable in some samples. The degree of alteration varies over the intrusion, and from the nature of the mineralogy it is difficult to assess whether it is due to hydrothermal alteration, low-grade regional metamorphism, or both.
Microbe analyses of plagioclase, augite, and opaques from a typical sample are presented in Table 1 (Sample 1). The augite is zoned, with cores enriched in $\mathrm{Ti}, \mathrm{A} 1, \mathrm{Mg}$ and depleted in $\mathrm{Fe}$ and $\mathrm{Mn}$ relative to rims.

Medium-grained subophitic to ophitic textures are typical of the gabbro, except in the sample from near the presumed margin (locality 18) which is fine-grained and intergranular in texture. In some areas, the gabbro is very coarse-grained and pegmatoid, and may contain large primary amphibole crystals. Such zones are gradational into normal gabbro and presumably represent more fluid-rich areas of the magma.

Evidence of brittle deformation in the intrusion is the abundance of fractured grains and deformed twin lamellae in most samples. Samples from actual shear zones (e.g. localities 4, 13) are more leucocratic than typical gabbro. In thin section, these samples display cataclastic textures and intense alteration. Fine-grained interstitial potassium feldspar (revealed by staining following the method of Hutchison 1974, p. 16) is abundant in these samples. This mineral, as well as the more leucocratic character of the rock (also reflected in its chemical composition, as discussed in the next section) are probably secondary, the result of hydrothermal alteration.

In the vicinity of localities 8 and 9 (Fig. 2), the rock is very leucocratic, and consists of albitic plagioclase (Table 1, Sample 8) rimmed by potassium feldspar. Mafic minerals are virtually absent, except for very minor chlorite and hematite. This rock may represent a more differentiated phase of the magma, but is more likely the result of alteration, as discussed in the following section.

\section{GEOCHEMISTRY}

Chemical analyses of 18 samples from the Mavillette Intrusion are presented in Table 2. The obvious mineralogical alteration observed to some extent in 
TABLE la - MICROPROBE ANALYSES OF FELDSPARS

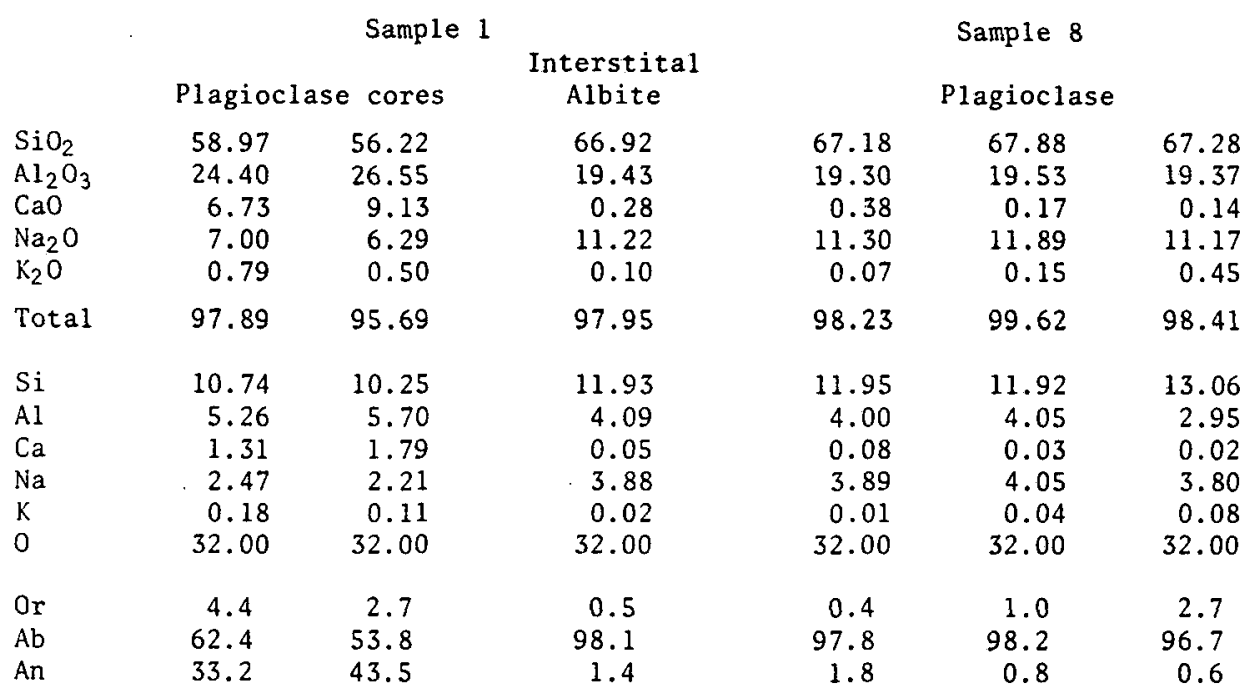

TABLE $1 \mathrm{~b}$ - MICROPROBE ANALYSES OF PYROXENES AND OPAQUES, SAMPLE 1

\begin{tabular}{|c|c|c|c|c|c|c|c|c|}
\hline & & & Pyroxe & & & & I $1 \mathrm{~m}$ & te \\
\hline & & Cores & & & & & & \\
\hline $\mathrm{SiO}_{2}$ & 50.55 & 50.72 & 50.67 & 51.05 & 50.91 & & - & - \\
\hline $\mathrm{TiO}_{2}$ & 1.30 & 1.46 & 1.18 & 0.73 & 0.92 & & 49.08 & 48.14 \\
\hline $\mathrm{Al}_{2} \mathrm{O}_{3}$ & 2.48 & 2.57 & 2.15 & 1.42 & 1.75 & & - & - \\
\hline $\mathrm{FeO}$ & 9.80 & 9.89 & 11.04 & 12.25 & 12.12 & & 48.16 & 47.99 \\
\hline MgO & 14.00 & 13.52 & 13.17 & 12.25 & 12.68 & & - & - \\
\hline $\mathrm{CaO}$ & 20.57 & 21.20 & 20.60 & 20.55 & 20.32 & & - & - \\
\hline $\mathrm{Na}_{2} \mathrm{O}$ & 0.32 & 0.28 & 0.33 & 0.42 & 0.30 & & - & - \\
\hline Mno & 0.20 & 0.19 & 0.20 & 0.32 & 0.38 & & 2.28 & 2.47 \\
\hline $\mathrm{Cr}_{2} \mathrm{O}_{5}$ & 0.15 & 0.17 & 0.00 & 0.17 & 0.06 & & - & - \\
\hline Total & 99.37 & 100.00 & 99.34 & 99.16 & 99.44 & & 99.52 & 98.60 \\
\hline $\mathrm{Si}$ & 1.90 & 1.90 & 1.92 & 1.95 & 1.94 & & - & - \\
\hline $\mathrm{Ti}$ & 0.04 & 0.04 & 0.03 & 0.02 & 0.03 & & 1.91 & 1.87 \\
\hline $\mathrm{Al}$ & 0.11 & 0.17 & 0.10 & 0.06 & 0.08 & & - & - \\
\hline $\mathrm{Fe}$ & 0.31 & 0.31 & 0.35 & 0.39 & 0.39 & & 2.08 & 2.08 \\
\hline $\mathrm{Mg}$ & 0.79 & 0.75 & 0.75 & 0.70 & 0.72 & & - & - \\
\hline $\mathrm{Ca}$ & 0.83 & 0.85 & 0.84 & 0.84 & 0.83 & & - & - \\
\hline $\mathrm{Na}$ & 0.02 & 0.02 & 0.02 & 0.03 & 0.02 & & - & - \\
\hline Mn & 0.007 & 0.007 & 0.007 & 0.01 & 0.01 & & 0.10 & 0.11 \\
\hline $\mathrm{Cr}$ & 0.004 & 0.005 & $0.00^{\prime}$ & 0.006 & 0.002 & & - & - \\
\hline 0 & 6.00 & 6.00 & 6.00 & 6.00 & 6.00 & & 6.00 & 6.00 \\
\hline $\mathrm{Ca}$ & 43.2 & 44.4 & 43.3 & 43.6 & 43.3 & $T \mathbf{i}$ & 46.7 & 46.2 \\
\hline $\mathrm{Fe}$ & 16.0 & 16.2 & 18.2 & 20.2 & 20.2 & $\mathrm{Fe}$ & 50.9 & 51.2 \\
\hline $\mathrm{Mg}$ & 40.8 & 39.4 & 38.5 & 36.2 & 37.5 & $\mathrm{Mn}$ & 2.4 & 2.6 \\
\hline
\end{tabular}

all samples indicates that the chemistry may also have been modified. Although loss on ignition values are generally quite low, they are highest in samples with the most secondary chlorite and amphibole.

The gabbroic samples range in $\mathrm{SiO}_{2}$ content from about $45 \%$ to $51 \%$ whereas the more leucocratic samples $(4,8,9,13)$ contain higher $\mathrm{SiO}_{2}$, ranging up to $63 \%$
(Table 2). Most elements show reasonable correlation with $\mathrm{SiO}_{2}$ (Fig. 3), except $\mathrm{Al}_{2} \mathrm{O}_{3}, \mathrm{MnO}, \mathrm{P}_{2} \mathrm{O}_{5}, \mathrm{Rb}, \mathrm{Ni}$ and $\mathrm{Cr}$. The significance of this scatter in an unrelated group of elements is unclear, although variation in $\mathrm{P}_{2} \mathrm{O}_{5}$ is correlated with varying modal apatite content. The chemical features of the more leucocratic samples $(4,8,9,13)$ could have been the result of differentiation, but petrographic and field evidence already 

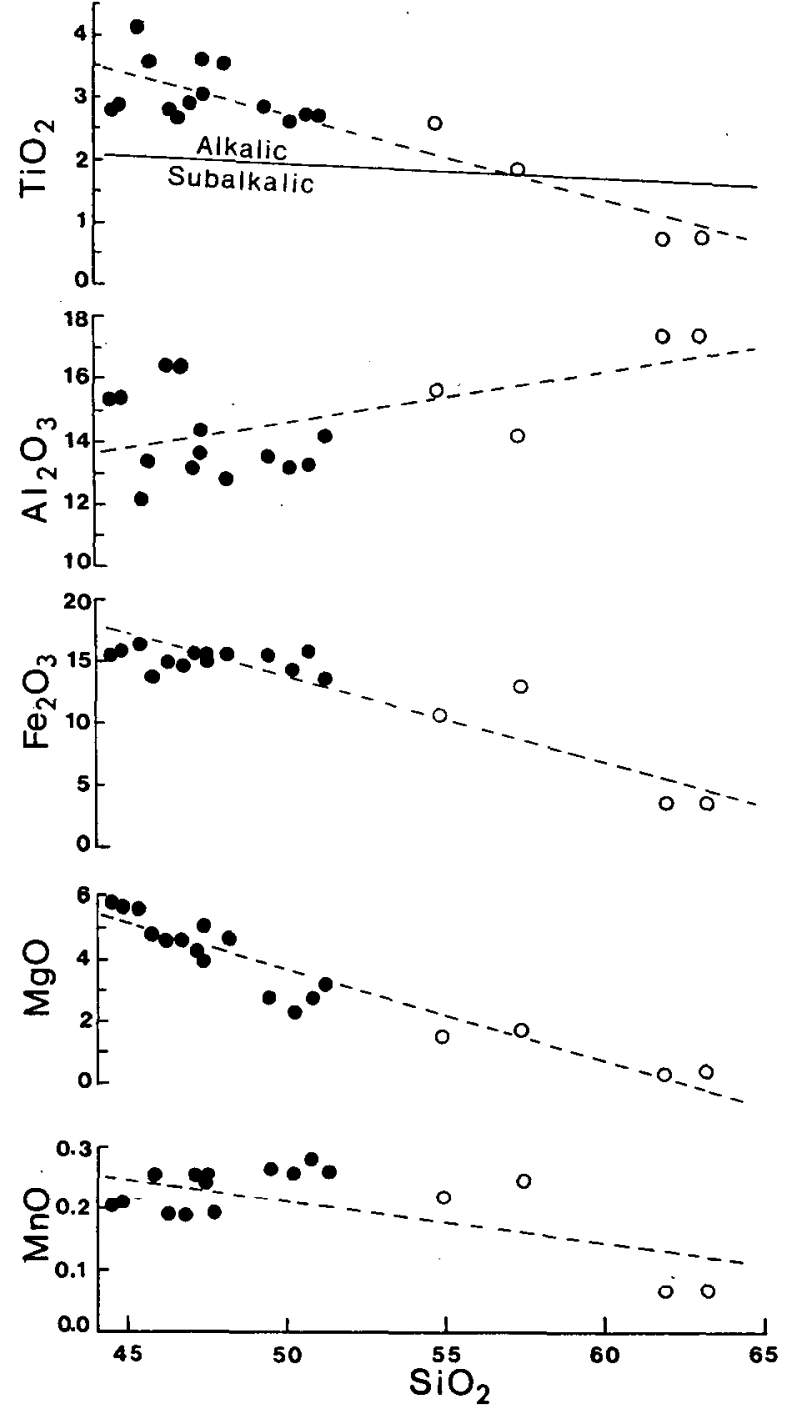

g. 3 - a,b,c - Silica variation diagrams for 18 samples from the Mavillette Intrusion. Alkalic/subalkalic dividing lines from Whitehead and Goodfellow 1978 ( $\left.\mathrm{TiO}_{2}\right)$ and Irvine and $\mathrm{Baragar} 1971$ ( $\mathrm{Na} 2 \mathrm{O}+\mathrm{K}_{2} \mathrm{O}$ ) . $\mathrm{Closed}$ circles = gabbroic samples from Mavillette Intrusion. Open circles = 1eucocratic samples 4, 8, 9 , 13. Calcu-. lated linear regression lines are shown. Correlation coefficients for these 1 ines are -0.89 ( $\mathrm{TiO} \mathrm{O}_{2}$ ), 0.52 $\left.\left(\mathrm{Al}_{2} \mathrm{O}_{3}\right),-0.92\left(\mathrm{Fe}_{2} \mathrm{O}_{3} \mathrm{~T}\right),-0.94(\mathrm{MgO}),-0.67(\mathrm{MnO}),-0.94(\mathrm{CaO}), 0.91\left(\mathrm{Na}_{2} 0\right), 0.95\left(\mathrm{~K}_{2} \mathrm{O}\right),-0.43\left(\mathrm{P}_{2} \mathrm{O}\right)_{5}\right), 0.95$ $\left(\mathrm{Na}_{2} \mathrm{O}+\mathrm{K}_{2} \mathrm{O}\right), 0.95(\mathrm{Ba}), 0.55(\mathrm{Rb}), 0.74(\mathrm{Nb}), 0.77(\mathrm{Y}), 0.89(\mathrm{Zr}),-0.68(\mathrm{Ni})$, and $-0.30(\mathrm{Cr})$. 


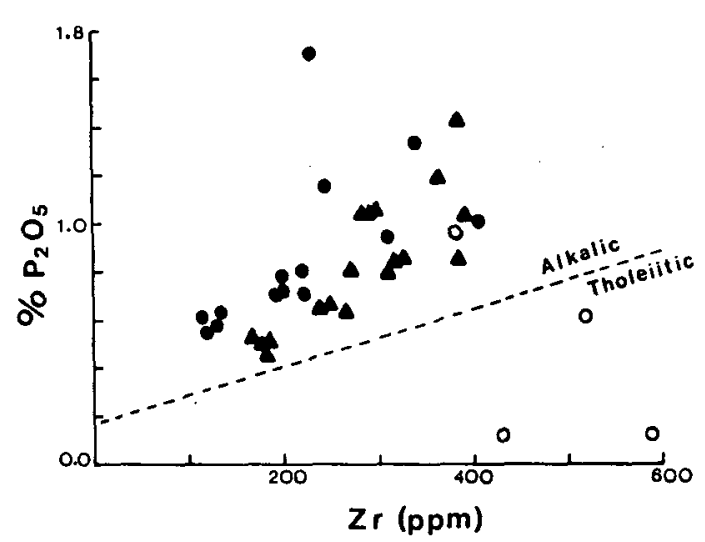

Fig. $4-\mathrm{P}_{2} \mathrm{O}_{5}-\mathrm{Zr}$ diagram. Alkalic/tholeittic dividing line is from Winchester and Floyd (1976). Symbols are as in Fig. 3 except triangles are compositions of samples from the upper volcanic unit of the White Rock Formation from Sarkar (1978).

described suggest that at least samples 4 and 13 were originally typical gabbro which have subsequently been altered. Samples 8 and 9 are not so clearly the product of alteration, but they could represent the extreme result.

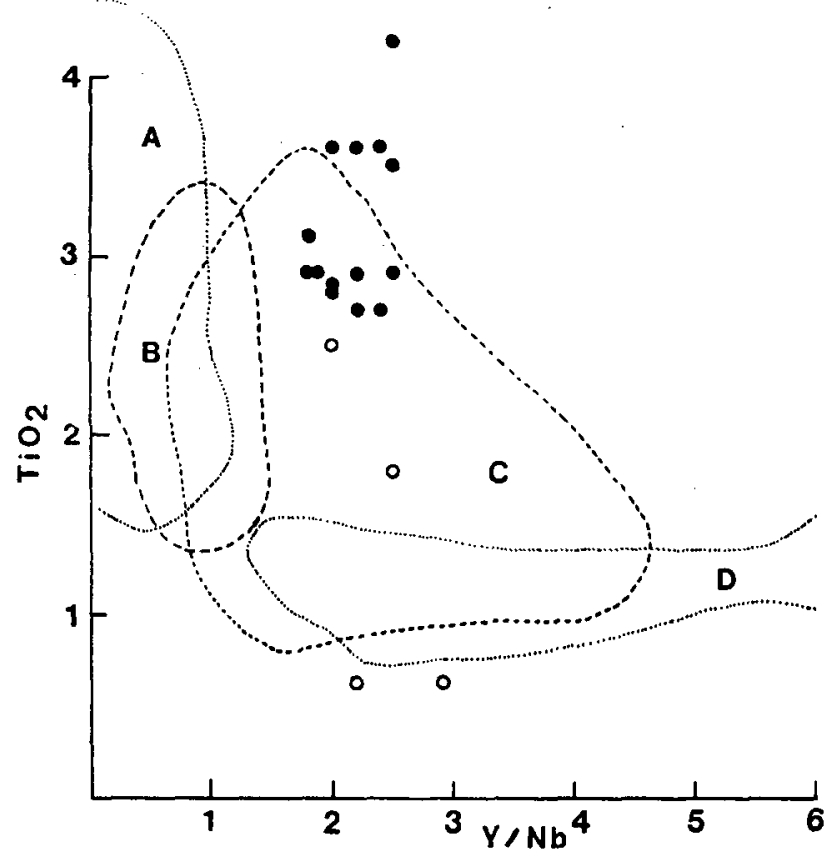

In some respects, the Mavillette Intrusion appears alkalic, as indicated by high $\mathrm{TiO}_{2}, \mathrm{P}_{2} \mathrm{O}_{5}$, total alkalies, $\mathrm{Ba}$, $\mathrm{Rb}$, and $\mathrm{Ni} / \mathrm{Cr}$ (Fig. 3a, b, c; Fig. 4; c.f. Pearce and Cann 1973; Floyd and Winchester 1975; Winchester 1976; de Albuquerque 1979). Many samples show normative nepheline (Table 2). However, other, probably more reliable, indicators suggest that the intrusion is tholeiitic (Fig. 5). Although the samples are high in $\mathrm{TiO}_{2}$, their $\mathrm{Y} / \mathrm{Nb}$ ratios are too high for alkalic rocks and place them in or near the continental tholeiite field (Fig. 5a). Similarly, although $\mathrm{P}_{2} \mathrm{O}_{5}$ is high, the ratio $\mathrm{Zr} / \mathrm{P}_{2} \mathrm{O}_{5}$ varies with approximately constant $\mathrm{Nb} / \mathrm{Y}$, a trend typical of tholeiitic rocks, and also places these samples in the continental tholeiite field (Fig. 5b).

Hence, it appears that the Mavillette Intrusion may represent a highly fractionated continental tholeiite magma. This is further supported by the high iron contents and low $\mathrm{MgO} / \mathrm{FeO}^{\mathrm{T}}$ ratios in the samples. Such highly evolved

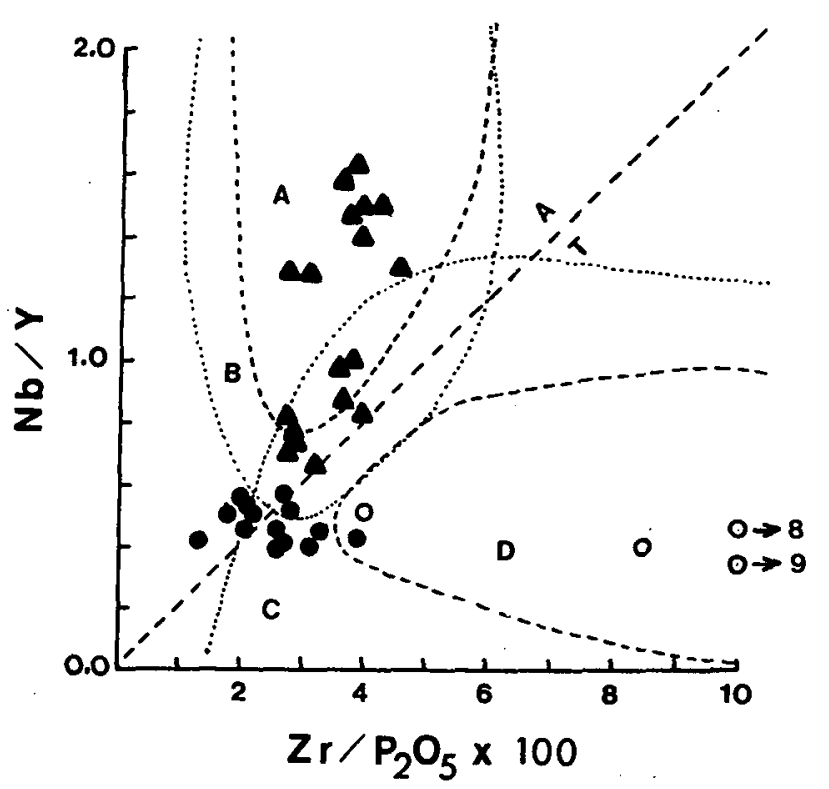

Fig. 5 - (a) $\mathrm{TiO}_{2}-\mathrm{Y} / \mathrm{Nb}$ diagram. Field boundaries from Floyd and Winchester (1975). $A=$ oceanic alkalic basalts; $B=$ continental alkalic basalts; $C=$ continental tholeittic basalts; $\mathrm{D}=$ oceanic tholeiitic basalts. Symbols as in Fig. 3. (b) $\mathrm{Nb} / \mathrm{Y}-$ $\mathrm{Zr} / \mathrm{P}_{2} \mathrm{O}_{5}$ diagram. Alkalic/tholeiitic dividing line from Floyd and Winchester (1975). Fields and symbols as in (a) and Fig. 4. Non-mafic rocks are plotted on these diagrams for mafic rocks only for comparison. 
TABLE 2 - CHEMICAL ANALYSES AND CIPW NORMATIVE MINERALOGIES*

\begin{tabular}{|c|c|c|c|c|c|c|c|c|c|c|c|c|c|c|c|c|c|c|}
\hline & 1 & 2 & 3 & 4 & 5 & 6 & 7 & 8 & 9 & 10 & 11 & 12 & 13 & 14 & 15 & 17 & 18 & 19 \\
\hline $\mathrm{SiO}_{2}$ & 45.9 & 49.4 & 50.9 & 55.0 & 51.1 & 44.6 & 45.5 & 63.1 & 62.0 & 48.1 & 46.2 & 47.5 & 47.4 & 50.1 & 44.9 & 46.8 & 47.5 & 47.1 \\
\hline $\mathrm{TiO}_{2}$ & 3.6 & 2.9 & 2.7 & 2.5 & 2.7 & 2.9 & 4.2 & 0.7 & 0.7 & 3.5 & 2.8 & 3.6 & 1.8 & 2.7 & 2.9 & 2.8 & 3.1 & 2.9 \\
\hline $\mathrm{Al}_{2} \mathrm{O}_{3}$ & 13.6 & 13.8 & 13.3 & 15.7 & 14.2 & 15.5 & 12.1 & 17.7 & 17.6 & 13.0. & 16.5 & 13.7 & 14.2 & 13.3 & 15.5 & 16.4 & 14.3 & 13.2 \\
\hline $\mathrm{Fe}_{2} \mathrm{O}_{3} \mathrm{~T}$ & 16.5 & 15.2 & 15.6 & 11.0 & 13.5 & 15.3 & 16.2 & 3.4 & 3.3 & 15.9 & 14.9 & 14.7 & 12.8 & 14.0 & 16.0 & 14.5 & 16.0 & 15.8 \\
\hline $\mathrm{MnO}$ & 0.25 & 0.25 & 0.27 & 0.22 & 0.25 & 0.21 & 0.23 & 0.06 & 0.06 & 0.23 & 0.19 & 0.25 & 0.24 & 0.25 & 0.21 & 0.19 & 0.24 & 0.25 \\
\hline $\mathrm{MgO}$ & 4.9 & 2.8 & 2.9 & 1.6 & 3.2 & 5.8 & 5.7 & 0.4 & 0.4 & 4.8 & 4.7 & 3.9 & 1.8 & 2.3 & 5.8 & 4.7 & 5.0 & 4.2 \\
\hline $\mathrm{CaO}$ & 9.6 & $5.6^{\circ}$ & 7.3 & 6.1 & 8.6 & 8.4 & 9.7 & 0.9 & 1.0 & 8.7 & 9.1 & 8.8 & 2.8 & 6.2 & 9.0 & 8.7 & 7.2 & 8.8 \\
\hline $\mathrm{Na}_{2} \mathrm{O}$ & 3.4 & 5.2 & 4.2 & 5.7 & 4.8 & 3.5 & 3.8 & 7.8 & 7.6 & 4.6 & 3.6 & 4.3 & 4.5 & 4.4 & 3.0 & 3.3 & 4.5 & 3.6 \\
\hline $\mathrm{K}_{2} \mathrm{O}$ & 1.2 & 1.3 & 2.2 & 2.2 & 1.7 & 1.0 & 1.2 & 4.3 & 4.3 & 1.3 & 1.1 & 1.4 & 2.4 & 1.7 & 1.1 & 1.3 & 1.4 & 1.8 \\
\hline $\mathrm{P}_{2} \mathrm{O}_{5}$ & 0.72 & 1.33 & 0.94 & 0.95 & 1.16 & 0.63 & 0.78 & 0.12 & 0.12 & 0.70 & 0.61 & 0.80 & 0.61 & 1.05 & 0.56 & 0.58 & 0.70 & 1.70 \\
\hline LOI & 1.3 & 2.3 & 1.1 & 1.4 & 1.3 & 2.2 & 1.4 & 1.0 & 0.8 & 1.0 & 1.7 & 1.3 & 1.9 & 5.4 & 2.1 & 2.3 & 1.7 & 1.3 \\
\hline Total & 101.0 & 100.1 & 101.4 & 102.4 & 102.5 & 100.0 & 100.8 & 99.5 & 97.2 & 101.4 & 104.4 & 100.3 & 100.5 & 101.4 & 101.1 & 101.6 & 101.6 & 100.7 \\
\hline$Q$ & 0.0 & 0.0 & 0.0 & 1.5 & 0.0 & 0.0 & 0.0 & 0.0 & 0.0 & 0.0 & 0.0 & 0.0 & 11.1 & 3.8 & 0.0 & 0.0 & 0.0 & 0.0 \\
\hline $0_{\dot{r}}$ & 7.0 & 7.8 & 13.0 & 13.0 & 9.7 & 6.3 & 7.1 & 25.5 & 26.2 & 7.6 & 6.4 & 8.4 & 14.4 & 10.2 & 6.4 & 8.0 & 8.4 & 11.0 \\
\hline$A b$ & 28.8 & 45.9 & 36.0 & 48.0 & 40.7 & 28.2 & 28.2 & 66.9 & 65.3 & 33.6 & 29.7 & 34.6 & 38.5 & 38.8 & 25.8 & 28.1 & 34.8 & 30.7 \\
\hline An & 18.9 & 10.6 & 11.2 & 10.9 & 12.1 & 24.2 & 12.7 & 0.8 & 1.2 & 11.0 & 26.0 & 14.3 & 10.2 & 12.5 & 26.3 & 26.7 & 15.2 & 14.8 \\
\hline $\mathrm{Ne}$ & 0.0 & 0.0 & 0.0 & 0.0 & 0.0 & 1.4 & 2.5 & 0.0 & 0.7 & 3.0 & 0.6 & 2.4 & 0.0 & 0.0 & 0.0 & 0.0 & 1.8 & 0.0 \\
\hline Di & 12.2 & 3.4 & 6.7 & 5.6 & 10.0 & 7.6 & 18.1 & 2.4 & 2.2 & 14.3 & 7.5 & 13.2 & 0.0 & 4.5 & 7.7 & 6.6 & 7.7 & 8.1 \\
\hline $\mathrm{Hy}$ & 9.4 & 14.0 & 19.0 & 8.3 & 8.9 & 4.5 & 6.8 & 0.0 & 0.0 & 8.2 & 5.4 & 7.1 & 15.3 & 16.1 & 17.8 & 10.2 & 5.6 & 13.3 \\
\hline Fo & 4.1 & 1.1 & 0.2 & 0.0 & 2.2 & 8.1 & 4.2 & 0.0 & 0.0 & 3.8 & 5.9 & 2.7 & 0.0 & 0.0 & 6.9 & 4.0 & 6.4 & 2.8 \\
\hline $\mathrm{Fa}$ & 3.4 & 1.7 & 0.4 & 0.0 & 2.5 & 6.1 & 2.0 & 0.0 & 0.0 & 2.7 & 5.3 & 1.8 & 0.0 & 0.0 & 5.8 & 3.5 & 5.9 & 3.1 \\
\hline Wo & 0.0 & 0.0 & 0.0 & 0.0 & 0.0 & 0.0 & 0.0 & 0.1 & 0.1 & 0.0 & 0.0 & 0.0 & 0.0 & 0.0 & 0.0 & 0.0 & 0.0 & 0.0 \\
\hline Mt & 7.5 & 6.6 & 6.2 & 5.8 & 6.1 & 6.6 & 8.4 & 1.3 & 1.2 & 7.3 & 6.4 & 7.6 & 4.9 & 6.4 & 6.6 & 6.3 & 6.8 & 6.6 \\
\hline II & 7.0 & 5.7 & 5.2 & 4.8 & 5.1 & 5.6 & 8.1 & 1.4 & 1.4 & 6.7 & 5.4 & 7.1 & 3.5 & 5.4 & 5.6 & 5.3 & 6.0 & 5.7 \\
\hline $\mathrm{Hm}$ & 0.0 & 0.0 & 0.0 & 0.0 & 0.0 & 0.0 & 0.0 & 1.4 & 1.5 & 0.0 & 0.0 & 0.0 & 0.0 & 0.0 & 0.0 & 0.0 & 0.0 & 0.0 \\
\hline Ap & 1.7 & 3.2 & 2.0 & 2.2 & 2.7 & 1.5 & 1.8 & 0.3 & 0.3 & 1.6 & 1.4 & 1.9 & 1.5 & 2.6 & 1.3 & 1,4 & 1.6 & 4.0 \\
\hline c & 0.0 & 0.0 & 0.0 & 0.0 & 0.0 & 0.0 & 0.0 & 0.0 & 0.0 & 0.0 & 0.0 & 0.0 & 0.7 & 0.0 & 0.0 & 0.0 & 0.0 & 0.0 \\
\hline $\mathrm{Ba}$ & n.d. & n.d. & n.d. & n.d. & 423 & 445 & 380 & 1292 & 1375 & 505 & 342 & 410 & 802 & 605 & 315 & 384 & $1955 ?$ & 502 \\
\hline $\mathrm{Rb}$ & 31 & 35 & 42 & 33 & 32 & 23 & 21 & 36 & 31 & 23 & 17 & 23 & 41 & 29 & 27 & 30 & 26 & 36 \\
\hline $\mathrm{Nb}$ & 18 & 29 & 28 & 29 & 25 & 17 & 17 & 28 & 26 & 20 & 15 & 21 & 34 & 28 & 16 & 16 & 20 & 22 \\
\hline$Y$ & 43 & 64 & 62 & 57 & 55 & 32 & 42 & 61 & 75 & 50 & 30 & 41 & 84 & 66 & 31 & 32 & 35 & 34 \\
\hline $\mathrm{Zr}$ & 200 & 340 & 310 & 380 & 245 & 135 & 200 & 430 & 590 & 220 & 115 & 220 & 520 & 406 & 120 & 130 & 190 & 230 \\
\hline $\mathrm{Ni}$ & 39 & 58 & 32 & 24 & 39 & 76 & 26 & 0 & 0 & 52 & 58 & 50 & 39 & 11 & 95 & 111 & 73 & 34 \\
\hline Cr & 30 & 16 & 32 & 15 & 22 & 58 & 27 & 19 & 41 & 13 & 32 & 18 & 16 & 17 & 52 & 28 & 31 & 26 \\
\hline
\end{tabular}

* Calculated using $\mathrm{Fe}_{2} \mathrm{O}_{3}=1.5+\mathrm{TiO}_{2}$ (Irvine and Bargar 1971) and excluding trace elements $\begin{array}{ll}\text { n.d. } & \text { not determined } \\ \text { LOI } & \text { loss on ignition }\end{array}$ 
tholeiites can display chemical characteristics such as high $\mathrm{P}_{2} \mathrm{O}_{5}$ and $\mathrm{TiO}_{2}$ more commonly associated with alkalic rocks, combined with low $\mathrm{Ni}$ and $\mathrm{Cr}$ (e.g. Skaergaard Intrusion; Wager and Brown 1968).

Additional evidence for chemical affinities can be obtained from clinopyroxene compositions (Nisbet and Pearce 1977). Unfortunately the discriminant function plot places the clinopyroxenes of the Mavillette Intrusion in very ambiguous positions (Fig. 6). However, comparison of their compositions with average clinopyroxene compositions from

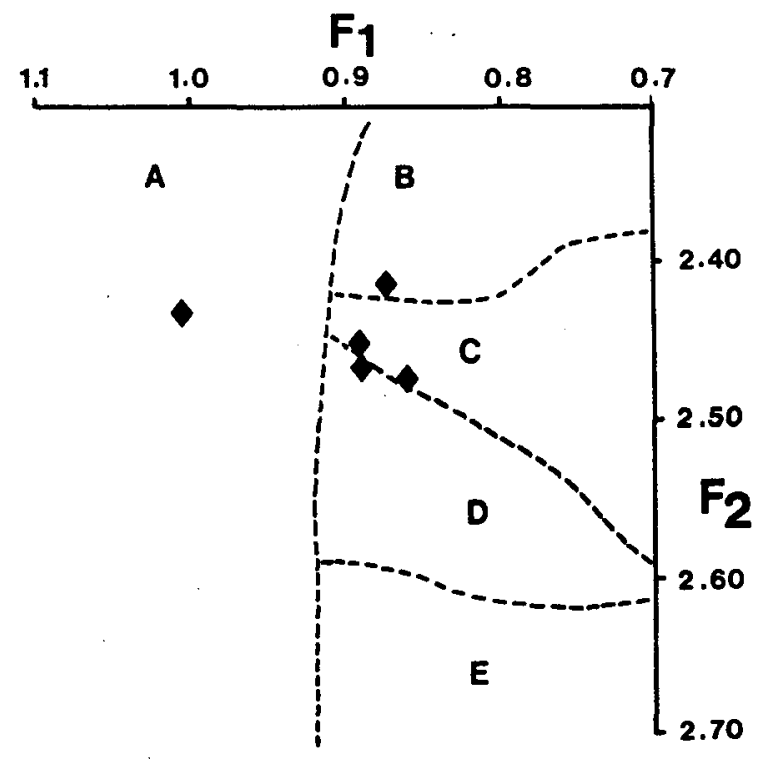

Fig. 6 - Pyroxene analyses from the Mavillette Intrusion (Table $1 \mathrm{~b}$ ) plotted on the discriminant diagram of Nisbet and Pearce (1977). A = within-plate alkalic basalts; $B=$ volcanic arc basalts; $C=$ volcanic arc basalts + ocean floor basalts; $D=$ ocean floor basalts + within-plate tholeiitic basalts; $E=$ within-plate basalts.

various tectonic settings (Nisbet and Pearce 1977) reveals more overall similarity to clinopyroxenes from withinplate tholeites than to those from alkalic basalt, especially in $\mathrm{TiO}_{2}$ and $\mathrm{Na}_{2} \mathrm{O}$ contents, although alkalic basalt pyroxenes do show large deviations in these elements.

Taken as a whole, the geochemistry indicates a continental tectonic setting. Additional geochemical plots devised more directly for this purpose also support this interpretation. The mafic samples from the Mavillette Intrusion plot in the continental field on the $\mathrm{FeO}^{\mathrm{T}}-\mathrm{MgO}-\mathrm{Al}_{2} \mathrm{O}_{3}$ diagram (Pearce et al. 1977) (Fig. 7a). The "immobile" elements, $T i, Z r$, and $Y$, place most samples in the "within-plate" field (oceanic or continental) (Fig. 7b), although with increasing silica content the samples form a trend towards the $\mathrm{Zr}$ corner as a result of strong positive correlation between $\mathrm{SiO}_{2}$ and $\mathrm{Zr}$ (Fig. $3 c)$.

COMPARISON WITH OTHER MAFIC IGNEOUS ROCKS IN SOUTHERN NOVA SCOTIA

Both the Mesozoic Shelburne dyke (Papezik and Barr 1981) and North Mountain basalt (Wark and Clarke 1980) (Fig. 1) are also basically continental tholeiites, although with some oceanic characteristics, and the Mavillette Intrusion could represent a highly evolved related magma. However, the degree and type of alteration/metamorphism in the Mavillette Intrusion makes this correlation seem unlikely.

Although the alteration is similar, the Mavillette Intrusion also differs from the lower Palaeozoic mafic sills of the Bear River, Nictaux-Torbrook, and Wolfville-Kentville areas of western Nova Scotia which are predominantly tholeiitic but oceanic rather than continental (Doyle 1979; Trapasso 1979; Barr et a. . in preparation). It is distinctly different from calc-alkalic mafic plutonic rocks apparently associated with Devonian intrusive activity in southern Nova Scotia (de Albuquerque 1979).

The Mavillette Intrusion seems most likely to be related to the volcanic rocks of the White Rock Formation which are probably late Ordovician - early Silurian in age (Keppie and Dostal 1980). These volcanic rocks occur in geographic proximity to the Mavillette Intrusion (Fig. 1), and show similar histories of alteration/metamorphism and deformation. 

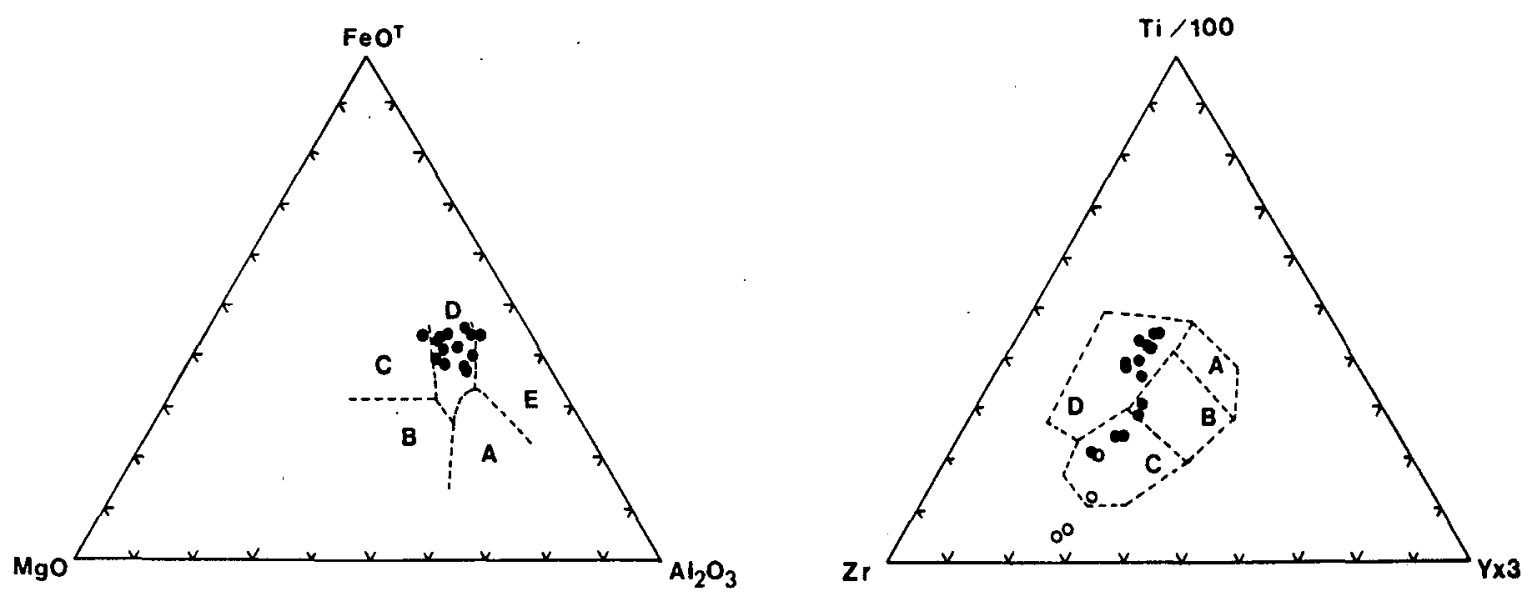

Fig. 7 - (a) $\mathrm{FeOT}_{-} \mathrm{MgO}-\mathrm{Al}_{2} \mathrm{O}_{3}$ diagram. Field boundaries from Pearce et al. (1977). Field $A=$ orogenic; $B=$ ocean floor and ridge; $C=$ ocean island; $D=$ continental; $\mathrm{E}=$ spreading centre island. Symbols as in Fig. 3. (b) Ti/100-Zr-Yx3 diagram.

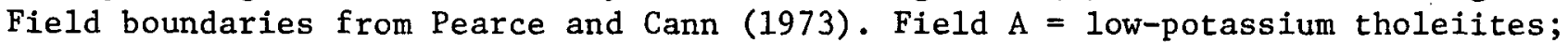
$B=$ ocean floor basalts, low-potassium tholeiites, and calc-alkalic basalts; $C=$ calc-alkalic basalts; $D=$ within-plate basalts (oceanic island or continental). Symbols as in Fig. 3. Non-mafic rocks are plotted only for comparison.

They include both tholeiitic and alkalic rocks, apparently formed in a "withinplate" continental setting (Keppie and Dostal 1980; Sarkar 1978). The chemical similarity between the Mavillette Intrusion and the upper volcanic unit of the White Rock Formation is particularly strong, including high $\mathrm{Fe}_{2} \mathrm{O}_{3} \mathrm{~T}$, $\mathrm{TiO}_{2}$, and $\mathrm{P}_{2} \mathrm{O}_{5}$ (e.g. Fig. 4). However, $\mathrm{Nb} / \mathrm{Y}$ ratios are higher in the White Rock volcanics and show a typically alkalic trend (Fig. $5 b)$.

\section{CONCLUSIONS}

The highly evolved, probably tholeiitic, chemistry of the Mavillette Intrusion is apparently unique in southern Nova Scotia. On the basis of its location and mineralogical and chemical features, the Mavillette Intrusion was probably emplaced as part of the same igneous episode as the White Rock volcanic suite in the late Ordovician or early Silurian.

\section{ACKNOWLEDGEMENTS}

We thank Shell Minerals Ltd. and Saarberg Interplan Canada Ltd. for loaning magnetometers for field work. The use of the electron microprobe of the Department of Geology, Dalhousie Univer- sity, and the assistance of R. Mackay and $J$. Setter with the probe analyses are gratefully acknowledged. This project was supported in part by Grant A 3320 . to S. M. Barr from the Natural Sciences and Engineering Research Council of Canada. We also thank D. B. Clarke, J. Dostal, and V.S. Papezik for reviewing the manuscript. Their comments led to substantial improvements.

BARR, S.M., DOYLE, E.M. and TRAPASSO, L. S. (in preparation). Petrology and tectonic implications of mafic sills in lower Palaeozoic formations of southwestern Nova Scotia.

BUCKLEY, E.E. and CRANSTON, R.C. 1971. Atomic absorption analysis of 18 elements from a single decomposition of aluminosilicates. Chemical Geology, 1, pp. 273-284.

CALDER, L.M. 1981. Geology of the Mavillette Intrusion, Digby County, Nova Scotia. B.Sc. thesis, Acadia University, Wolfville, $216 \mathrm{p}$.

de ALBURQUERQUE, C.A.R. 1979. Origin of the plutonic mafic rocks of southern Nova Scotia. Geological Society of American Bulletin, 90, pp. 719-731.

Department of Mines and Technical Sur- 
veys (Geological Survey of Canada). 1956. Meteghan, Aeormagnetic map 6106, Sheet $21 \mathrm{~B} / 1,1: 63,360$.

DOYLE, E.M. 1979. Geology of the Bear River area, Digby and Annapolis Counties, Nova Scotia. M.Sc. thesis, Acadia University, Wolfville, $216 \mathrm{p}$.

FLOYD, P.A. and WINCHESTER, J. A. 1975. Magma type and tectonic setting discrimination using immobile elements. Earth and Planetary Science Letters, 27, pp. 211-218.

HUTCHISON, C.S. 1974. Laboratory handbook of petrographic techniques. WileyInterscience, $527 \mathrm{p}$.

IRVINE, T.N. and BARAGAR, W.R.A. 1971. A guide to the chemical classification of common volcanic rocks. Canadian Journal of Earth Sciences, 8, pp. 523-548.

KEPPIE, J. D. 1979. Geological map of the Province of Nova Scotia. N.S. Department of Mines and Energy, 1: 2,000,000.

KEPPIE, J.D. and DOSTAL, J. 1980. Paleozoic volcanic rocks of Nova Scotia. In "The Caledonides in the U.S.A." Edited by D.R. Wones. Virginia Polytechnic Institute and State University, Department of Geological Sciences. Blacksburg, Virginia, U.S.A. Memoir 2, pp. 249-256.

LAWRENCE, D.E. 1966. A contribution to the petrology of the Great Dike of Nova Scotia. M.Sc. thesis, Dalhousie University, Halifax, N.S., 108 p.

NISBET, E.G. and PEARCE, J.A. 1977. Clinopyroxene composition in mafic lavas from different tectonic settings. Contributions to Mineralogy and Petrology, 63, pp. 149-160.

PAPEZIK, V.S. and BARR, S.M. 1981. The Shelburne dike, an Early Mesozoic diabase dike in Nova Scotia: mineralogy, chemistry and regional significance. Canadian Journal of Earth Sciences, 18, pp. 1346-1355.

PEARCE, J.A. and CANN, J.R. 1973. Tec- tonic setting of basic volcanic rocks determined using trace element analyses. Earth and Planetary Science Letters, 19, pp. 290-300.

PEARCE, T.H., GORMAN, B.E. and BIRKETT, T.C. 1977. The relationship between major element chemistry and tectonic environment of basic and intermediate volcanic rocks. Earth and Planetary Science Letters, 36, pp. 121-132.

SARKAR, P.K. 1978. Petrology and geochemistry of the White Rock metavolcanic suite, Yarmouth, Nova Scotia. Ph.D. thesis, Dalhousie University, Halifax, N.S., 207 p.

TAYLOR, F.C. 1979. Geology of the Annapolis-St. Mary's Bay map-area, Nova Scotia. Geological Survey of Canada Memoir 358, 65 p.

TRAPASSO, L. 1979. The geology of the Torbrook Syncline, Kings and Annapolis Counties, Nova Scotia. M.Sc. thesis, Acadia University, Wolfville, 217 p.

WAGER, L.R. and BROWN, G.M. 1968. Layered Igneous Rocks. Oliver and Boyd, Edinburgh and London, $588 \mathrm{p}$.

WARK, J.M. and CLARKE, D.B. 1980. Geochemical discriminators and the paleotectonic environment of the North Mountain basalt, Nova Scotia. Canadian Journal of Earth Sciences, 17, pp. 1740-1745.

WHITEHEAD, R.E.S. and GOODFELLOW, W.D. 1978. Geochemistry of volcanic rocks from the Tetagouche Group, Bathurst, New Brunswick, Canada. Canadian Journal of Earth Sciences, 15, pp. 207-219.

WINCHESTER, J.A. 1976. Different Moinian amphibolite suites in northern Rossshire. Scottish Journal of Geology, 12, pp. 187-204.

WINCHESTER, J.A. and FLOYD, P. A. 1976. Geochemical magma type discrimination: Application to altered and metamorphosed basic igneous rocks. Earth and P1anetary Science Letters, 28, pp. 459-469.

REVIEWERS: J. DOSTAL D.B. CLARKE V.S. PAPEZIK 